\title{
GROWTH, FLOWERING AND FRUITING PERFORMANCE OF COFFEE (COFFEA ROBUSTA) AS INFLUENCED BY ORGANIC-BASED FORTIFIED FOLIAR FERTILIZER
}

\author{
Alminda Magbalot-Fernandez ${ }^{1}$, Daisy Fernandez ${ }^{2}$ and Saikat Kumar Basu ${ }^{3}$ \\ ${ }^{1}$ Rizal Memorial Colleges Inc. Davao City \\ ${ }^{2}$ University of Southeastern Philippines, Tagum-Mabini Campus \\ ${ }^{3}$ PS Lethbridge, AB Canada T1J 4B3
}

\section{Research Article \\ Received: 15.07.2020}

\begin{abstract}
The study was conducted to determine the effect of Greenshield Organic-Based Fortified Foliar Fertilizer on the growth, flowering and fruiting performance of Coffea robusta. The experiment was laid out using Randomized Complete Block Design (RCBD), having six treatments and three replications. The treatments were: T1 - Untreated check (No fertilizer); T2 - RR of NPK fertilizer/ha; T3 - 1/2 RR NPK/ha; T4 Greenshield Organic - Based Fortified Foliar Fertilizer at 100ml/li of water; T5-1/2 RR NPK + GOFF; and T6 - RR of NPK + GOFF. The result of the study revealed that different rates of Greenshield Organic - Based Fortified Foliar Fertilizer significantly affected the number of flowers and number of fruits, but not stem diameter.

Results showed that the number of flowers at 30 Days after application was increased by T6 - RR of NPK + GOFF up to 36\% higher than without applications. It also had the highest number of fruits in two weeks from flowering as much as $100 \%$ more fruits than GOFF alone and untreated. While no significant increase in terms of stem diameter was observed which ranged from 75 to $90 \mathrm{~cm}$ at 30 days after application.
\end{abstract}

Keywords:Growth, Flowering, Fruit, Coffea robusta, Organic, Foliar Fertilizer.

\section{INTRODUCTION}

Coffee (Coffea robusta), commonly known as Robusta coffee, is a species of coffee that has its origin in central $2^{\text {nd }}$ western Sub-Saharan Africa. It is a species of flowering plant in the Rubiaceae family. Though widely known as coffea robusta, the plant is scientifically identified as Coffea canephora, which has two main varieties, robusta and nganda. Coffee is one of the world's most popular beverages. Some claim it as the most widely consumed liquid in the world aside from water.

In 2011, production of coffee in Philippines was estimated at 88,526 MT. The number of bearing trees declined by $1.65 \%$ while area planted with coffee also declined by 1.43 percent which is 119,657 hectares from 121,399 hectares in 2010. Strong winds brought

*Corresponding author: almindafernandez5@gmail.com 
about by typhoons Mina, Pedring and Quiel aborted the development of berries in Benguet and La Union. Frequent rains adversely affected production in Sulatan Kudarat. There were reports of crop shifting to Señorita banana in Compostela Valley and to rubber in Zamboanga City. Nevertheless, Robusta remained as the major variety with 71.14 percent share in the 2011 production. The top producers of coffee in 2011 were SOCCSKSARGEN, Davao Region and ARMM with respective shares in the national production of 30.94 percent, 23.13 percent and 12.31 percent, respectively (Bureau of Agricultural Statistics).

Hence, an effective fertilizer management is vital to optimize coffee production. Foliar feeding addresses the immediate needs of a growing crop, as opposed to long-term soil deficiencies, by spraying water-soluble fertilizers onto the leaf surface of the plants. All plants absorb nutrients through their leaves and stems, using stomata-little openings similar to the pores of our skin. Plants absorb foliar sprays 20 times faster than soil-applied nutrients. Foliars help plants compensate for soil deficiencies (low fertility, low soil temperature, etc.) during the growing season (Tisdale and Nelson 1996). Foliar fortify plants facing other types of stress as well, such as drought, heat, cold, mechanical or insect damage or the onset of disease-susceptible periods. Foliar feeding can also be timed to encourage and/or enhance critical points in the plant's growth cycle, such as seedling emergence or rapid growth phases or flowering, fruiting and seed formation. Many crops benefit from 6-8 foliar applications per season. Some growers apply weekly foliar at low concentrations to improve nutrient balance (Recto 2009).

Organic-based materials include, but are not limited to, biosolids, activated sludge, municipal compost, animal manures (e.g., horse, cow, chicken, pig, and/or sheep), and composted organic by products. Other organic - based materials include processed animal body and vegetable products such as blood meal, feather meal, cottonseed meal, ocean kelp meal, and fish fertilizers such as fish emulsions or meal. The use of organic fertilizer and microbial material is an important part of this new attempt to make Agriculture a usable part of a healthy ecosystem. This is also vital in the rehabilitation of areas that have been exploited on annual crops or forestry in a non-sustainable way (PCARRD 1982).

On the other hand, using organic fertilizers makes the farmers increase their interest and awareness in the more efficient use of fertilizer through proper application rates, timing and methods of application. In addition to this, farmer should pay more attention to the integration and better utilization of rural waste, farm manure, agricultural waste and residues along with the use of nitrogen fixing legumes in crop rotation and green physical, chemical and biological properties of the soil. Hence, this study was conducted to determine the effect of Greenshield Organic - Based Fortified Foliar Fertilizer on the growth, flowering and fruiting performance of coffee and identify the best fertilizer treatment for the growth, flowering and fruiting of coffee.

\section{MATERIALS AND METHODS}

The experiment was conducted at the research area of the University of Southeastern Philippines from October 2015 - January 2016. The 20 year old rejuvenated Coffee 'robusta' Trees already planted in $6 \times 6 \mathrm{~m}^{2}$ were used. The soil samples were taken at random from the experimental area at the depth of $30 \mathrm{~cm}$. The soil was pulverized, airdried, sieved, and analyzed at the Department of Agriculture, Regional Soil Laboratory in Davao city. The study was conducted using Randomized Completely Block (RCBD) with six treatments and was replicated three times having two plants per treatment. The treatments were: T1 Untreated check (no fertilizer); T2 Recommended rate of NPK fertilizer /ha based on soil analysis; T3-1/2 Recommended NPK/ha; T4Greenshield Organic - Based Fortified Foliar Fertilizer at $100 \mathrm{ml} / 16 \mathrm{li}$ of water; T5 - 1/2 recommended NPK + GOFF; and T6 - 
recommended rate of NPK + GOFF. Weed control was done manually at three weeks interval using grass hook. The fertilizer was applied through ring application at the radius of $75 \mathrm{~cm}$ with six (6) holes from the base and covered with soil.

The recommended amount of fertilizer based on soil analysis (Organic Fertilizer $=30$ to $40 \mathrm{kgs}$ per plant per year; Ammophos(16-20-0) $=500$ to 1000 grams per plant per year; Ammosul (21-0-0$24)=405$ to 810 grams per plant per year; Urea $(46-0-0)=185$ to 370 grams per plant per year; and Muriate of Potash $(0-0-60)=250$ to 500 grams per plant per year) was applied to the trees based on the treatments. The recommended rate of Greenshield Organic - Based Fortified Foliar Fertilizer was sprayed on trees using knapsack sprayer every ten days at $100 \mathrm{ml}$ per 16 liters of water. Plants were sprayed with insecticide and fungicide as pest and symptoms of disease appeared. Pruning was done to remove those parts that are undesirable to the plant system. This was done to prevent the presence of water sprouts.

The stem diameter was determined by measuring the 2 representative samples per treatment per replication at 15 days interval. Measurement was done at $50 \mathrm{~cm}$ from base of the stem using caliper. The number of flower per branch at N, S, E, and W points were taken during flowering within the duration of the study. The numbers of fruit berries per branch of all experimental plants were counted one month from flowering. The different data gathered were analyzed through Analysis of Variance (ANOVA) following the Randomized Complete Block Design (RCBD) and effectiveness of different treatments was determined by comparing means using the Honest Significant Difference (HSD) Test at 5\% level of significance.

\section{RESULTS AND DISCUSSION}

\section{Stem Diameter Increment (cm)}

Statistical analysis showed no significant differences among treatment in stem diameter of coffee at 15 days after application (Table 1 and Figure 1). Results showed that stem diameter of 20 year old coffee ranged from $74-94 \mathrm{~cm}$. Diameter increased after 15 - 30 days after application which ranged from $0.3-1.8 \mathrm{~cm}$. This implies that both basal and foliar fertilizer application has no influence on the stem diameter growth of coffee.

Inoko (1984) reported that organic fertilizer is not immediately available to the plants due to slow release. Thus, the continuous application of organic matter results to accumulation of nutrients of the soil. The accumulated nutrients are gradually utilized by the successive cropping (Brady 1974).

Table 1: Means on the stem diameter $(\mathrm{cm})$ Increment of coffee as influenced by Greenshield Organic - Based Fortified Foliar Fertilizer (GOFF).

\begin{tabular}{|l|c|c|c|}
\hline \multicolumn{1}{|c|}{ Treatment } & \multicolumn{2}{c|}{$\begin{array}{c}\text { Stem Diameter (cm) Increment } \\
\text { Days after application } \\
\mathbf{1 5}^{\text {ns }}\end{array}$} \\
\hline T1 - Untreated check (no fertilizer) & 75.17 & 0.6667 & 0.8333 \\
\hline T2 - Recommended Rate of NPK fertilizer/ha & 74.66 & 0.5000 & 1.1667 \\
\hline T3 - 1/2 Recommended NPK/ha & 87.33 & 0.8333 & 1.6667 \\
\hline $\begin{array}{l}\text { T4 - Greenshield Organic - Based Fortified Foliar Fertilizer at } \\
100 \text { ml/16liters of water }\end{array}$ & 83.17 & 0.3333 & 1.1667 \\
\hline T5 - 1/2 Recommended NPK + GOFF & 81.17 & 0.8333 & 1.8333 \\
\hline T6 - Recommended Rate of NPK + GOFF & 94 & 0.6667 & 1.3333 \\
\hline C.V = \% & & 39.56 & 41.08 \\
\hline
\end{tabular}

ns - not significant

Means with the same letter are not significantly different at 5\% level using HSD. 


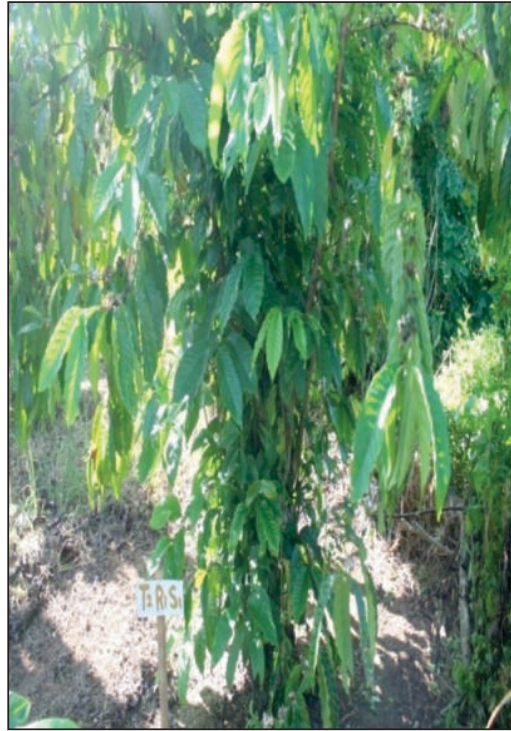

T1. Untreated check (no fertilizer)

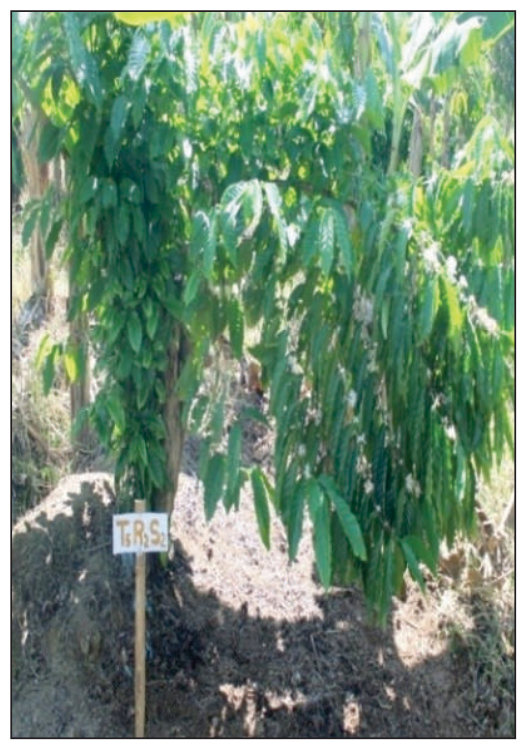

T4. GOFF at $100 \mathrm{ml} / 16$ liters of water

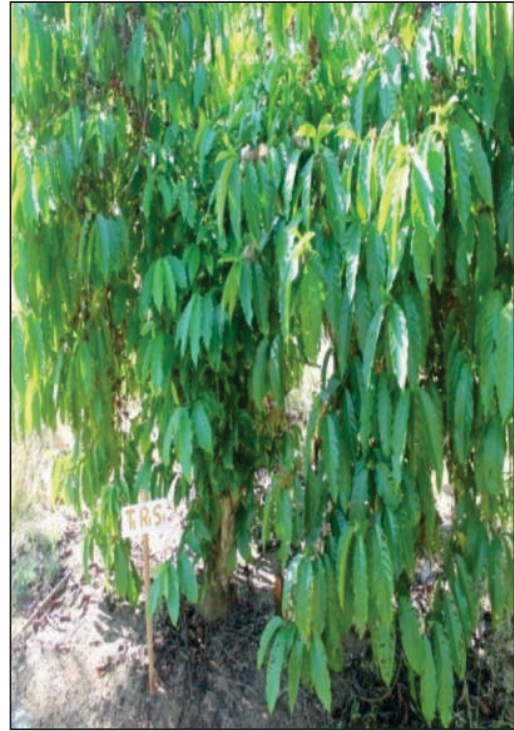

T2. RR of NPK fertilizer/ha

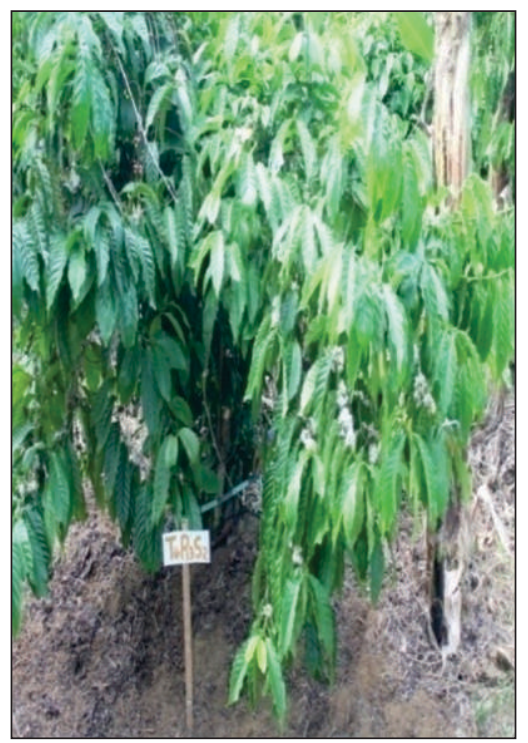

T5. 1/2 Recommended NPK+GOFF

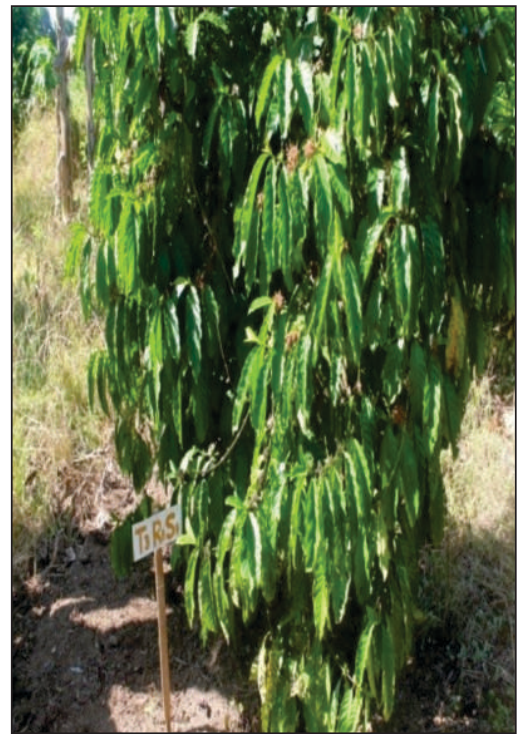

T3. 1/2 Recommended NPK/ha

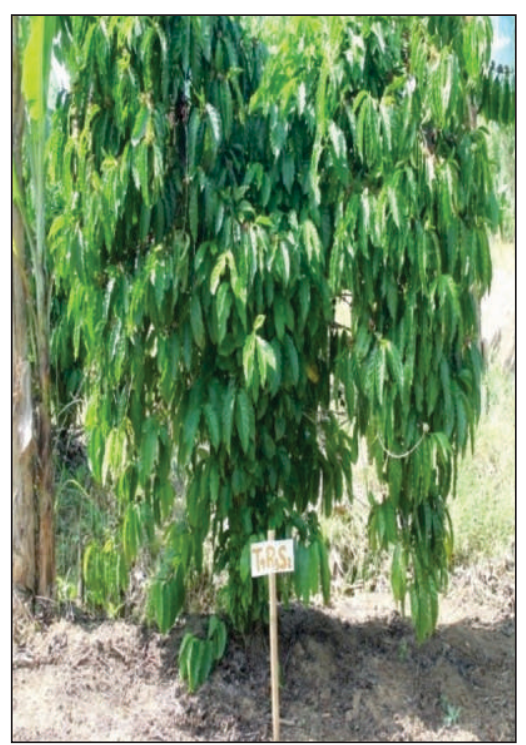

T6. RR of NPK + GOFF

Figure 1: Growth Performance of Coffee (Coffea robusta) as Influenced by Greenshield OrganicBased Fortified Foliar Fertilizer.

\section{Number of Flowers per Branch}

The number of flowers of coffee at 30 days after application (DAA) was significantly affected by Greenshield Organic - Based Fortified Foliar
Fertilizer (GOFF), but not at 15 DAA (Table 2 and Figure 2). Results indicate that at 30 days after application (DAA), the number of flowers was 
increased by GOFF + RR NPK (T6) up to $36 \%$ higher than without application. Both basal and foliar fertilizer applications were statistically the same to T6 - RR of NPK + GOFF and to no application (control). While at 15 DAA basal and foliar applications did not differ statistically in terms of number of flowers. Greenshield Organic
- Based Fortified Foliar Fertilizer contains macro elements such as NPK and microelements like zinc, Manganese, Magnesium, Calcium, Cupper, Iron, Boron fortified with organic base for the maximum growth of various crops, fruits and vegetables (Magbalot-Fernandez, personal communication).

Table 2: Means on the number of flowers per branch of coffee as Influenced by Greenshield Organic - Based Fortified Foliar Fertilizer (GOFF).

\begin{tabular}{|c|c|c|}
\hline \multirow[t]{2}{*}{ Treatment } & \multicolumn{2}{|c|}{$\begin{array}{c}\text { Number of flowers per Branch } \\
\text { Days after application }\end{array}$} \\
\hline & $15^{\mathrm{ns}}$ & $30^{*}$ \\
\hline T1 - Untreated check (no fertilizer) & 86.33 & $77.250^{\mathrm{b}}$ \\
\hline T2 - Recommended Rate of NPK fertilizer/ha & 91.210 & $83.877^{\mathrm{ab}}$ \\
\hline T3-1/2 Recommended NPK/ha & 101.127 & $99.877^{\mathrm{ab}}$ \\
\hline $\begin{array}{l}\text { T4 - Greenshield Organic - Based Fortified Foliar Fertilizer } \\
\text { at } 100 \mathrm{ml} / 16 \text { liters of water }\end{array}$ & 87.917 & $91.627^{\mathrm{ab}}$ \\
\hline T5 - 1/2 Recommended NPK + GOFF & 91.503 & $101.627^{\mathrm{ab}}$ \\
\hline T6-Recommended Rate of NPK + GOFF & 99.920 & $105.877^{\mathrm{a}}$ \\
\hline $\begin{array}{l}\text { C.V = \% } \\
\text { ns - not significant } \\
\text { *- significant }\end{array}$ & 5.67 & 10.54 \\
\hline
\end{tabular}

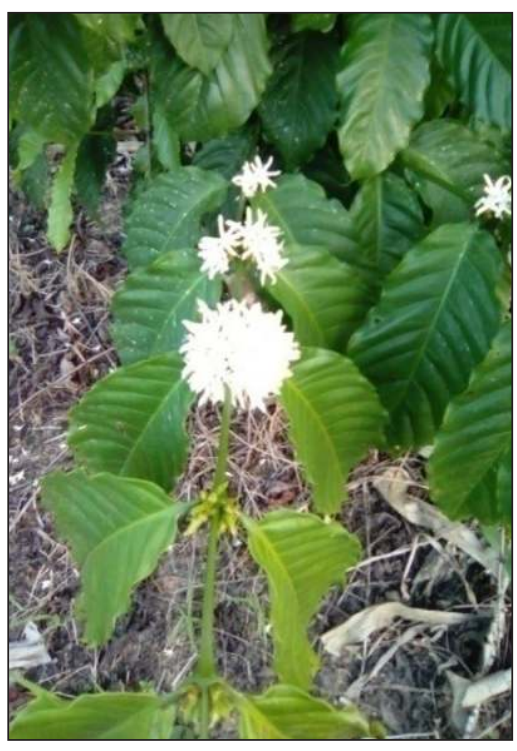

T1. Untreated check (no fertilizer)

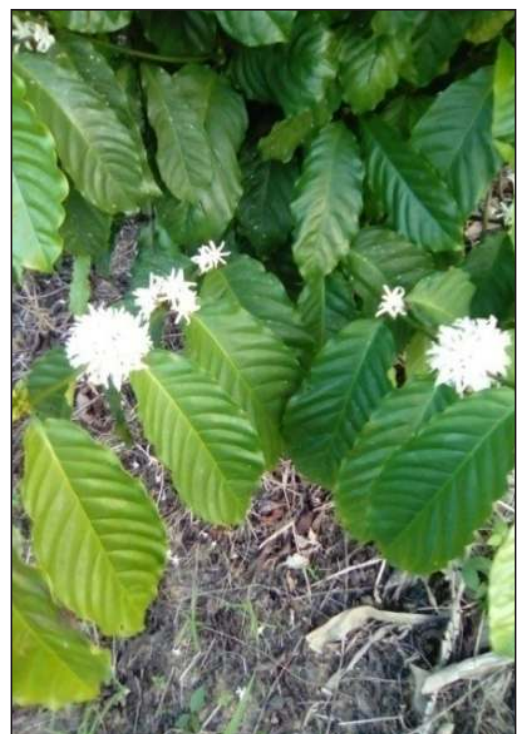

T2. RR of NPK fertilizer/ha

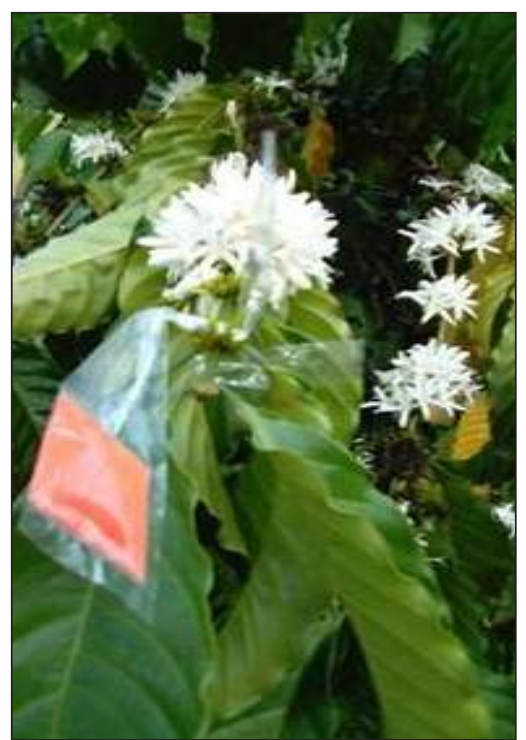

T3. 1/2 Recommended NPK/ha 


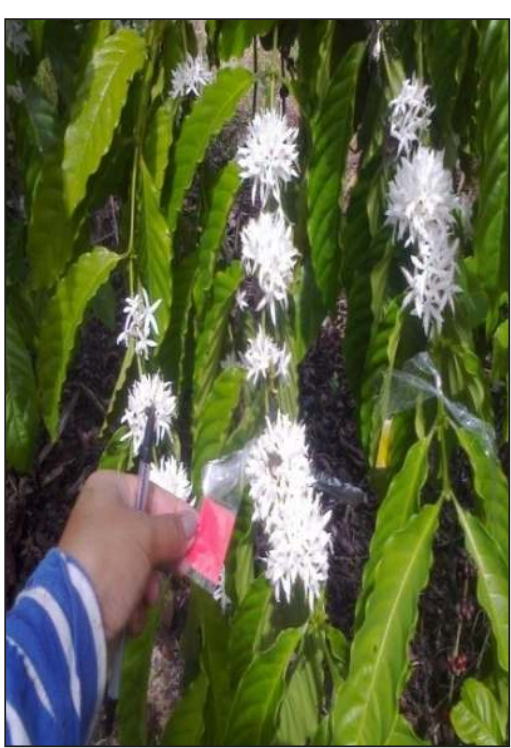

T4. GOFF at $100 \mathrm{ml} / 16$ liters of water

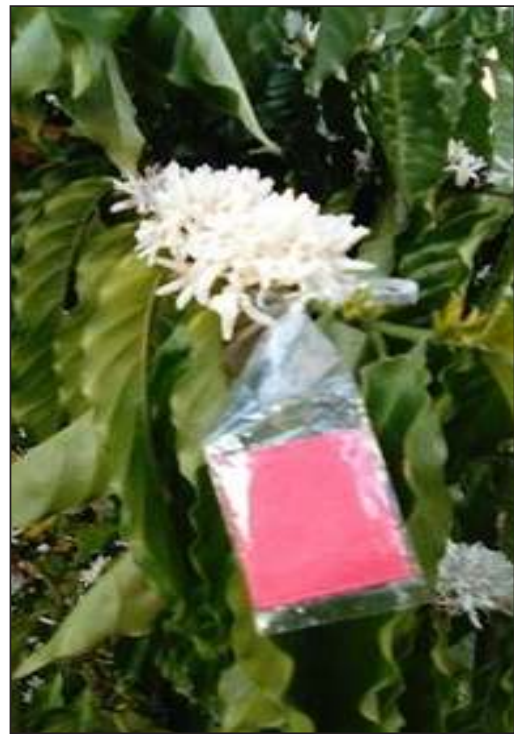

T5. $1 / 2$ Recommended NPK+GOFF

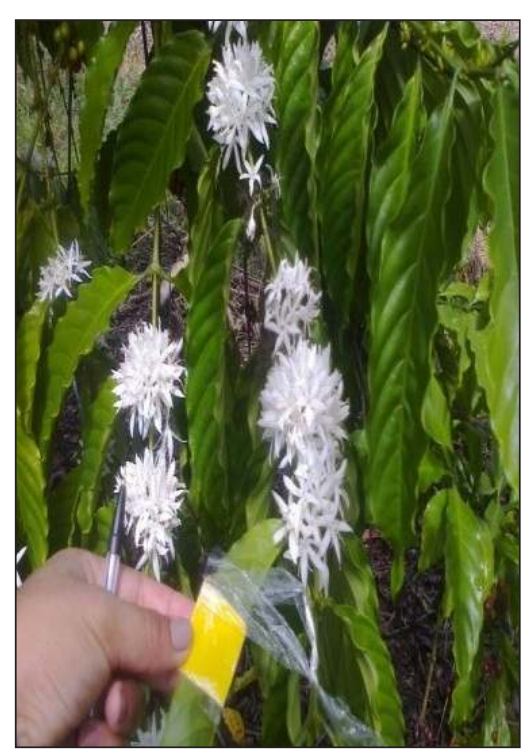

T6. RR of NPK + GOFF

Figure 2: Number of Flowers of Coffee as Influenced by Greenshield Organic - Based Fortified Foliar Fertilizer.

\section{Number of Fruits per Branch}

Table 3 and Figure 3 show the number of fruits per branch of coffee after two weeks from flowering as affected by Greenshield Organic - Based Fortified Foliar Fertilizer (GOFF). Results showed that highest number of fruits is obtained in T6- RR NPK + GOFF which is $100 \%$ more fruits than the Greenshield Organic - Based Fortified Foliar Fertilizer (GOFF). It is also similar to T5- 1/2 RR NPK + GOFF (T3 + T4), T3$1 / 2$ RR NPK/ha and T2- RR of NPK fertilizer/ha. While lowest number of fruits is observed in T4GOFF at $100 \mathrm{ml} / 16$ liter of water and T1Untreated check (no fertilizer).

Table 3: Number of fruits per branch of coffee as Influenced by Greenshield Organic-Based Fortified Foliar Fertilizer (GOFF).

\begin{tabular}{|l|c|c|c|c|c|}
\hline \multicolumn{1}{|c}{ Treatment } & \multicolumn{2}{c}{ Replication } & \multicolumn{3}{c}{$\begin{array}{c}\text { Average Fruits } \\
\text { per Branch } \\
\text { Total }\end{array}$} \\
Mean**
\end{tabular}

C.V $=\%$ 21.43

ns - not significant

*- significant

Means in column with the same letters are not significantly different at 5\% level using HSD. 
Castillo (2009) confirmed that foliar spray supplement significantly increased yields. In addition, plant growth, quality of fruits, weight of fruits and yield of coffee and cacao were enhanced through nitrogen, phosphorus and other organic fertilizers (Duallo 2015; Quinaso 2012; Celmar 2011; Cipriano 2010; Villanueva 2009; Masig 2008; Golingay 2007).

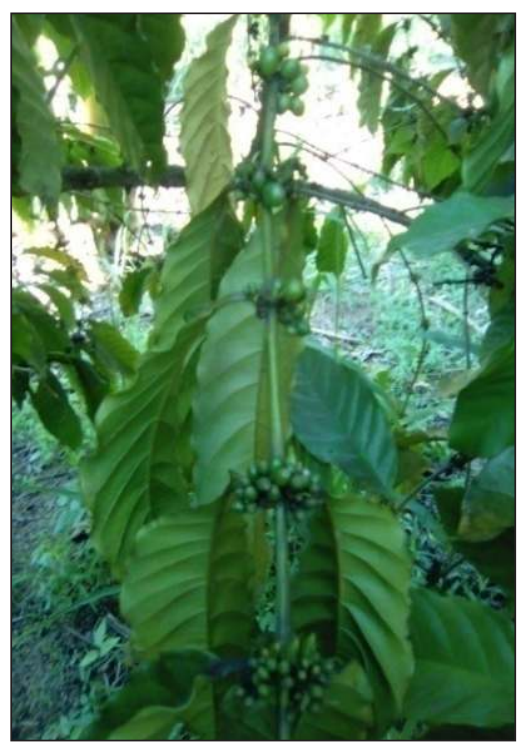

T1. Untreated check (no fertilizer)

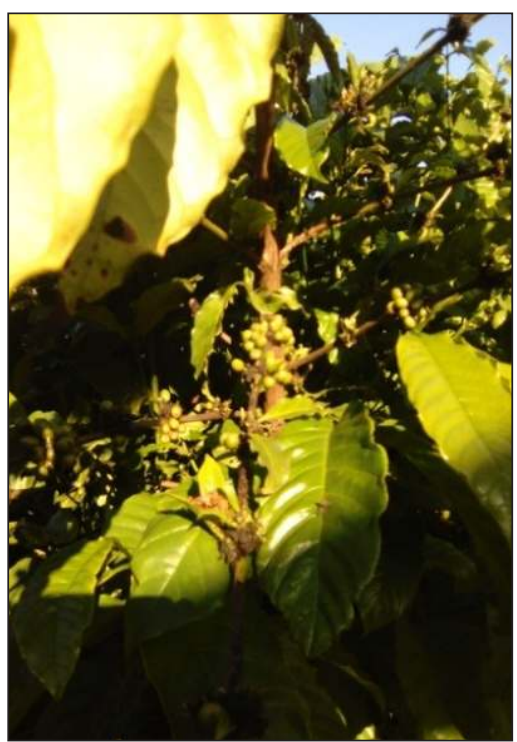

T4. GOFF at $100 \mathrm{ml} / 16$ liters of water

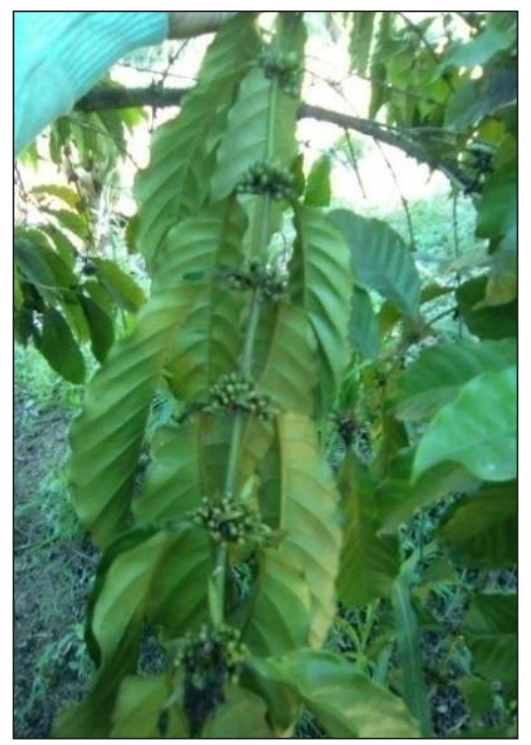

T2. RR of NPK fertilizer/ha

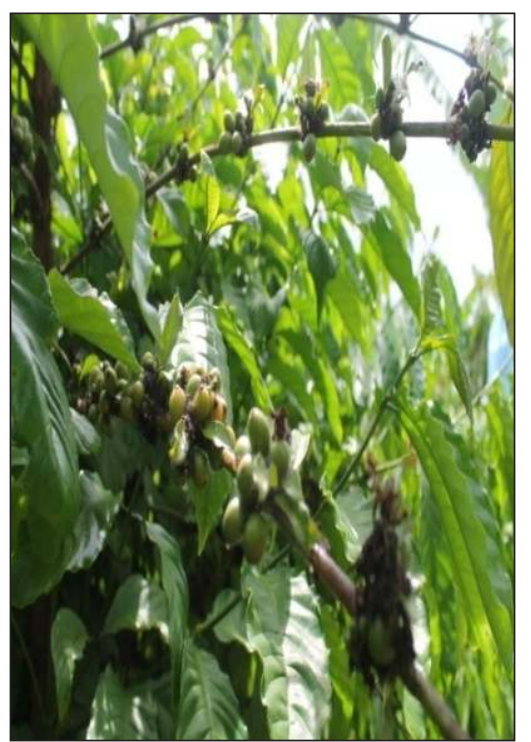

T5. 1/2 Recommended NPK + GOFF

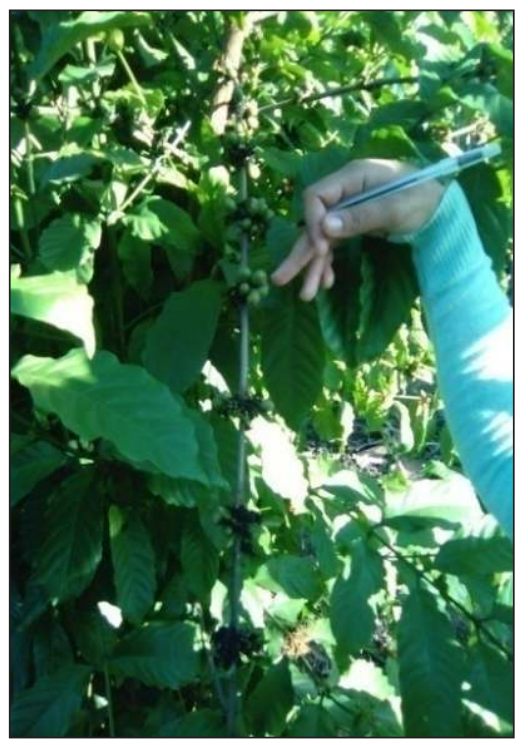

T3. 1/2 Recommended

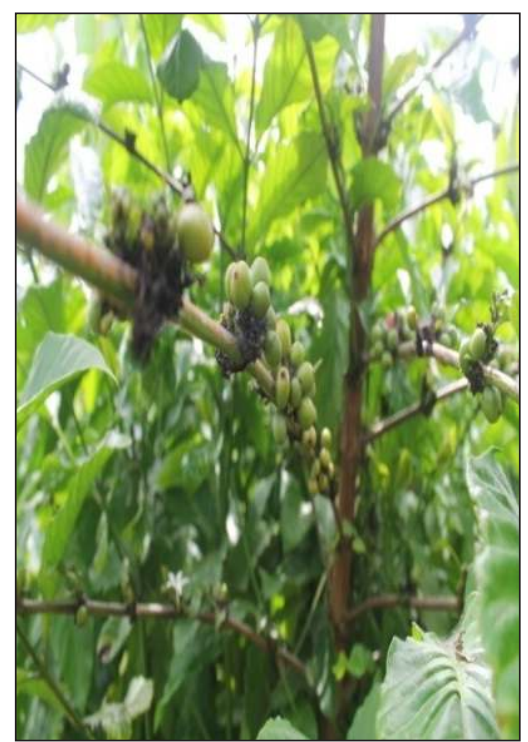

T6. RR of NPK + GOFF

Figure 3: Number of Fruits of Coffee as Influenced by Greenshield Organic - Based Fortified Foliar Fertilizer. 


\section{CONCLUSION}

The result of the study revealed that the Greenshield Organic-based Fortified Foliar fertilizer significantly affected the number of flowers, and number of fruits, but not stem diameter. Stem diameter ranged from 75 to $95 \mathrm{~cm}$ after 30 days of application. Results showed that the number of flowers at 30 DAA was increased by T6 - RR of NPK + GOFF up to 36\% higher than without application. T6 - RR of NPK + GOFF also got the highest number of fruits in two weeks from flowering as much as $100 \%$ more fruits than GOFF alone and untreated.

Hence, the combination of both basal NPK and GOFF enhanced the flowering and fruiting of coffea robusta. Further study on the effect of GOFF on the fruit weight and yield is highly recommended.

\section{REFERENCES}

1. BRADY, A. (1974). National and Properties of Soil. New York, Mc Graw HILL BOOK Co. Inc. pp. 23-

2. BUREAU OF AGRICULTURAL STATISTICS. Philippines

3. INOKO, A. (1984). Compost as a source of plant nutrients. https://agris.fao.org/agrissearch/search.do?recordID=XB8411353

4. CELMAR, J.A. (2011). Effect of Complete Fertilizer with Different Levels of Mycovam on the Growth of Coffee (Coffea robusta) rooted cuttings. Unpublished Undergraduate BSA Thesis. USeP-Tagum-Mabini Campus, Mabini Unit, Pindasan, Mabini Compostela Valley Province

5. CIPRIANO, J.P. (2010). Growth Performance of Coffee Seedlings (Coffea robusta) As Affected by the Different Level of Vermicast. Un published Undergraduate BSA Thesis. USeP-TagumMabini Campus, Mabini Unit, Pindasan, Mabini Compostela Valley Province
6. CASTILLO, R.U. (2009). Growth and Yield Performance of Corn (Zea mays) As Affected By Different Levels of NPK Fertilizer Supplemented with Nutriplant Foliar Fertilizer. Under Graduate BSA Thesis. USeP Tagum - Mabini Campus, Mabini Unit, Mampising, Compostela Valley Province.

7. DUALLO, V.B. (2015). Effect of Different Levels of Bokashi on Germination and Growth Performance of Cacao (Theobroma cacao) seedlings Supplemented with Foliar Fertilizer. Undergraduate BSA Thesis. USEP Tagum - Mabini Campus, Mabini Unit, Mampising, Mabini Compostela Valley Province.

8. GOLINGAY, P.A. (2007). The Influence of Nitrogen Fertilizer Application on the Yield of Rejuvenated Coffee (Coffea robusta). Undergraduate BSA Thesis. USEP Tagum Mabini Campus, Mabini Unit, Mampising, Mabini Compostela Valley Province.

9. MAGBALOT-FERNANDEZ, personal communication.

10. MASIG, K.L. (2008). Influence of Nitrogen Fertilizer Application on the Yield of Rejuvenated Coffee (Coffea robusta). Undergraduate BSA Thesis. USEP Tagum Mabini Campus, Mabini Unit, Mampising, Mabini Compostela Valley Province.

11. PCARRD (1982). The Philippine Recommends for Soil Fertility Management

12. PCARRD (1982). The Philippine Recommends for Banana.

13. QUINASO, J.N. (2012). Effect of Different Levels of Vermicast on the Growth of Coffee (Coffea robusta) Rooted Cuttings Supplemented with Mycovam and FermentedPlant Juice. Performance of Cacao (Theobroma cacao) seedlings Supplemented with Foliar Fertilizer. Undergraduate BSA Thesis. USEP Tagum - Mabini Campus, 
Mabini Unit, Mampising, Mabini Compostela Valley Province.

14. RECTO, R.B. (2009). Growth and Yield of Baby Corn (Zea mays L.) As Influenced by Different Distances of Planting Supplemented with Foliar Fertilizer. Unpublished Undergraduate BSA Thesis. USEP - Mabini Campus, Mampising, Mabini, Compostela Valley Province.
15. TISDALE, S.M. and W.I. NELSON (1975). Soil Fertility and Fertilizer. $3^{\text {3rd }}$ Edition Pp. 71, 72, 73, 74

16. VILLANUEVA, C.L. (2009). Growth and Performance of Coffee Seedlings (Coffeea robusta) Using Different Media Treated with BIO-N. Unpublished Undergraduate BSA Thesis. USEP - Mabini Campus, Mampising, Mabini, Compostela Valley Province. 